\title{
Volnost, rovnost, bratrství? Prvorepublikové vojenské festivity z pohledu nelegionářů
}

\section{Liberté - égalité - fraternité? Military commemorations of the First Czechoslovak Republic in non-legionary veterans perspective}

\author{
Lukáš Lexa/lexasb@email. cz \\ Historický ústav, Filozofická fakulta, Masarykova univerzita
}

\begin{abstract}
The focus of the paper is on the topic celebrations of anniversaries important for society of The First Czechoslovak Republic. Emphasis is put on the contrast between the celebrations of the Czechoslovak Legion and the sidelining of non-Legionary military activities after the First World War. The article covers the forms of commemorating during the representative festivities and the progressive development of their selection. The Czechoslovak Army posed an integral part of all of significant celebrations of the Czechoslovak nation. The study doesn't see the army exclusively as a stationary part of acts of reverence and commemorations, but also as an organiser of such festivities.
\end{abstract}

\section{Keywords}

Festivities, army, legionnaires, volunteers, militiamen, Czechoslovak Legion 


\section{Úvod}

Před sto lety se formovala moderní česká státnost. Ideály obyvatel prožívajících krizi první světové války se ubíraly mnoha směry. S odstupem můžeme tvrdit, že vedle politicky a nacionálně indiferentních osob kráčela většina vojáků za naplněním prosperity a svrchovanosti českého národa, byt’ v různých stejnokrojích, pod jiným velením a na opačných stranách fronty. Po destrukci monarchie a vzniku Československa se najednou tito vojáci měli postavit bok po boku a bojovat proti společnému nepříteli. Poražení vojáci bojující za rakouského císaře až do konečné porážky, vítězní legionáři a další účastníci prvního odboje se pospolu postavili za čs. stát při bojích na Těšínsku a Slovensku nebo v německojazyčných oblastech Československa. Paradoxně se tak pro československé vojáky uplatnilo až po rozpadu rakousko-uherské monarchie motto Viribus unitis. Spojenými silami bojovali proti nepřátelům, ale můžeme tuto spolupráci označit za harmonickou?

Vavro Šrobár při popisu doby etablování státního aparátu Československé republiky na Slovensku a války s Mad’ary konstatoval, že boje o integritu Československa přinesly kromě tisíců obětí na životech také něco pozitivního - sjednocení rozpolcené české a slovenské společnosti: „V tom bol klad Kúnovho útoku: neorganizovaných a nejednotných nás spojil k obrane našej vlasti. "1 Heslo Velké francouzské revoluce Volnost - rovnost bratrstvi recipované státotvorným sokolským hnutím v souvislosti s právním zrušením šlechtických titulů a ústavním zakotvením rovnosti občanů může navozovat dojem vskutku idylický. Realita však připomínala spíše tvoření nových „kast“ či elit. Českoslovenští legionáři si uvědomovali svưj význam pro formování státu a nekladli rovnítko mezi sebe a vojáky domácího vojska nebo čs. domobrany z Itálie. Pluralita názorů na směřování vývoje státního zřízení v Československu a nacionální, konfesní i majetkové otázky vrazily klín mezi obyvatele Československa, vojáky nevyjímaje.

Meziválečná československá armáda se hrdě hlásila k hnutí československých legionářů, mezi jejichž hesla patřilo bratrství, rovnost či sounáležitost a rovněž snaha o svobodný vývoj českého národa. Nedílnou součást armády a jejích záloh však tvořili také nelegionáři - vojáci bývalé monarchie, kteří do konce války sloužili císaři nebo dleli v zajateckých táborech. Následující řádky se věnují významným dnům prvorepublikové československé branné moci a jejich oslavám. Důraz je kladen na kontrast připomínání mezníků legionářského hnutí (resp. zahraničního odboje) a ne/připomínání popřevratových událostí (zejména obsazování Slovenska a Těšínska československými jednotkami). Studie se pokusí odpovědět na otázky, jak se vztah a pozice legionářů a nelegionářu v armádě a společnosti promítly do volby významných armádních dnů, státních svátků a průběhu jejich oslav, zda jednoznačně vítězila koncepce zahraničního odboje a docházelo dokonce k programovému opomíjení zásluh domácího vojska i čs. domobrany z Itálie, nebo bylo dosaženo konsenzu obou skupin.

Mezi nejvýznamnější svátky prvorepublikového Československa (a čs. armády) řadíme výročí vzniku samostatného státu 28. ř́ijna 1918 a výročí bitvy u Zborova 2. července 1917. Právě tyto svátky však podrobně popsali členové autorského kolektivu v knize Sláva re-

1 Vpád mad’arských bolševikov na Slovensko v roku 1919. Red. J. Zimák. Trnava b. d. , s. 10. 
publice!. Proto jim v této studii nebude věnována pozornost, která jim jinak nepochybně náleží. S ohledem na dlouhodobé badatelské zaměření autora článek sleduje problematiku z pohledu nelegionářských vojenských a polovojenských organizací a na ně navazujících veteránských spolků. Na rozdíl od knihy Sláva republice!, která sleduje spíše utváření svátkového kalendáře a nejvýznamnější festivity prvorepublikového Československa, se stat koncentruje na vojenské oslavy v širším slova smyslu, nejen oficiální památné dny, ale také jiná vojenská výročí v časovém rozmezí let 1918 až 1938.

\section{Dostupná pramenná základna a zvolená periodizace}

Pro studium průběhu oslav spjatých s armádou můžeme sáhnout jednak k dobovému tisku, kde najdeme poměrně podrobné reportáže z těchto akcí, dále ke kronikám obcí, souborným publikacím o dějinách vojenských jednotek a pamětním knihám jednotlivých útvarů. Dále též k archivnímu spisovému materiálu veteránských spolků, zemských vojenských velitelství či okresních úřadů. Jedná se o pestré spektrum pramenů, které přináší barvitý obraz zkoumaných událostí. Svobodné vyjádření protichůdných názorů přináší mnohdy i kritický náhled na některé aspekty oslav a soužití různých skupin obyvatelstva. Zvláště kriticky je třeba přistupovat k dobovému tisku krajní pravice či levice, nicméně právě zde lze mnohdy najít zajímavé podněty k dalšímu zkoumání.

Při pokusu o vytvoření základní periodizace musíme konstatovat, že nenajdeme přesné mezníky ohraničující jednotlivé etapy vývoje vzpomínkové kultury prvorepublikové československé armády. Jednoznačně můžeme vymezit počátek a konec sledovaného období (28. ř́ijen 1918 a 1. ř́ijen 1938), avšak tři základní sledovatelné etapy vývoje ceremonií meziválečné čs. armády se místy překrývají - dochází k evoluci bez vysledovatelnosti revolučních mezníků. Svátkový kalendář přijatý československým parlamentem v roce 1925 pro vojenské prostředí neznamená prakticky žádný předěl a nelze se k němu tedy upínat ani sledovat jeho vliv ve vojenském prostředí. ${ }^{2}$

První údobí lze charakterizovat jako dobu „společenského kvasu“. Docházelo v něm k nárůstu počtu oslav a jejich integraci ve veřejném prostoru. Časově jej můžeme zasadit do prvních dvou poválečných let (1918-1920). Druhá etapa představuje čas stabilizace, přestože se vojenské ceremonie neustále vyvíjely a odrážely polemiky ve společnosti. Jedná se o navazující období - léta 1921 až 1935. Třetí etapu můžeme označit jako dobu sjednocování, charakterizuje ji krize mezinárodní i vnitropolitické situace. Především v reakci na nárůst sympatií sudetských Němců k nacistickému hnutí v Německu a stupňujícím se požadavkům A. Hitlera se armádní i politické špičky Československa pokoušely zahladit stopy po vyčpělých sporech o zásluhy na vzniku státu a protlačovaly do popředí společný postup legionářů a nelegionářů při obraně republiky. ${ }^{3} \mathrm{Z}$ hlediska

2 Sláva republice! Oficiální svátky a oslavy v meziválečném Československu. Edd. D. Hájková - P. Horák V. Kessler - M. Michela. Praha 2018, s. 17.

3 Kárník, Zdeněk: České země v ére Proni republiky (1918-1938). Díl třetí. O přežití a o život (1936-1938). Praha 2003. Srov. Olivová, Věra: Dějiny proni republiky. Praha 2012²; Táž: Zápas o Československo. (ř́rjen 1937-záŕí 1938). Praha 1992. 
periodizace se nacházíme v posledních třech letech existence prvorepublikového Československa (1936-1938).

\section{Zvolené metody a kladené otázky}

Předkládaná studie pracuje formou několika sond s primárními prameny (archivním materiálem a dobovým tiskem). Kvůli omezenému rozsahu článku si neklade za cíl komplexní popis situace ve všech koutech někdejšího Československa. Jedná se o př́ípadovou materiálovou studii zkoumající festivity a vzpomínkovou kulturu meziválečné československé armády se zaměřením na české země (respektive moravský prostor s určitými přesahy). Spíše než z diskurzivního hlediska analyzuje prameny z obsahové stránky s cílem vytvoření základního přehledu problematiky postavení nelegionářských vojáků meziválečného Československa při formování vzpomínkové kultury a svátkového kalendáře i při oslavách samotných.

Studie se tedy pokusí odpovědět na základní otázky: kdy a jakým způsobem se etablovala vzpomínková kultura v československé armádě, jak se proměňovala skladba vojenských svátků a podoba ceremonií, jestli se objevovala kritika a alternativy, jakou roli sehrávaly zahraniční vlivy (například přítomnost francouzské vojenské mise při čs. armádě či nárůst fašismu) nebo jak konkrétně se projevilo ohrožení vlasti nacistickým Německem. V obecnějším smyslu jistě nepostrádají validitu ani otázky vycházející z př́istupů Michaela Maurera kladené v knize Sláva republice!. ${ }^{4}$ Podrobnější studium pramenů nabízí další otázky: jakou úlohu hráli po unifikaci čs. branné moci (v letech 1920-1938) na vzpomínkových akcích př́slušníci někdejšího domácího vojska a zda se dostali v rámci veteránských organizací do popředí zájmu veřejnosti a postavili se po boku legionářu nebo čs. domobrany z Itálie?

\section{Legionáři a outsideři}

Než se dostaneme k podrobnějšímu rozboru zkoumaných problémů, je třeba osvětlit základní rozdíly mezi jednotkami československých legií, domácího vojska, Slovácké brigády, pluků Stráže svobody a domobrany z Itálie. Je to klíčové pro pochopení následujícího textu. Nejedná se pouze o problém, na které straně fronty voják stál, ale taktéž o poměřování míry zásluh a „práce vykonané pro vlast“.

Československé legie (zpočátku pod jinými názvy) vznikaly živelně bez centrální organizace ihned po vzplanutí první světové války. První jednotky vznikly ve Francii a carském Rusku. Jednalo se zprvu o několik stovek až tisíců mužů. Teprve v pozdějších fázích války svolily úřady daných zemí k rozšíření početních stavů legií na desetitisíce mužů (uvádí se 90-100 tisíc). ${ }^{5}$ Jako poslední oficiální čs. legie se ustavila italská. Českoslovenští

4 Sláva republice!, s. 24.

5 K hlubšímu studiu problematiky viz Pichlík, Karel - Zabloudilová, Jitka - Klípa, Bohumír: Českoslovenšti legionár̆i (1914-1920). Praha 1996; Sak, Robert: Anabáze. Drama československých legionářů v Rusku (1914- 
dobrovolníci však sloužili také v Srbsku, Velké Británii, Černé Hoře, Austrálii, Kanadě nebo Spojených státech amerických, respektive v armádách těchto státních celků. Značná část legionářo̊ prošla peklem zákopové války ještě ve stejnokrojích rakousko-uherské armády. Poté, co se dostali do zajetí a přihlásili se do čs. dobrovolnických jednotek, prošli novými boji, mnohdy ještě krutějšími a nekonvenčnějšími. Zatímco čs. legionáři z Itálie a Francie se vraceli do vlasti v závěru roku 1918, poslední transporty čs. legionářu z Ruska přijížděly v říjnu 1920. Zvláštní skupinu tvořili dobrovolníci, kteří se (zejména v Rusku) přihlásili do čs. legií až po 28. říjnu 1918. Na tyto muže se formálně nepohlíželo jako na „legionáře podle zákona“, ${ }^{6}$ a nemohli tudíž požívat ani specifických výhod.

Domácí vojsko vzniklo krátce po převratu na půdorysu rakousko-uherské armády. Zahrnovalo muže, kteří pobývali v zázemí (v rekonvalescenci nebo týlovém zabezpečení), navrátilce $\mathrm{z}$ front, kteří bojovali prakticky do konce války na straně Ústředních mocností, ale taktéž zběhy, členy zelených kádrů nebo mladičké chlapce - dobrovolníky dosud nepovinné vojenskou službou. Pojila je služba čs. státu. Sehráli klíčovou roli v prvních momentech existence samostatné republiky, než se vrátili čs. legionáři. Státní správa reprezentovaná národními výbory vyzvala k formování dobrovolnických jednotek. K nim se na jihu a jihovýchodě Moravy řadila Slovácká brigáda. ${ }^{7} \mathrm{~V}$ dalších regionech vznikaly sokolské roty, prapory nebo pluky Stráže svobody. Slováci formovali Gardu slovenskej slobody nebo Sbor turčianských dobrovol’níkov. ${ }^{8}$ Jejich zásluhy na zvládnutí vrtkavé situace jsou neoddiskutovatelné, přesto nebyly součástí narativu vzniku čs. státu. Příslušníci domácího vojska se stali součástí většinové společnosti bez možnosti požívání zvláštních výhod. Paradoxně však státní orgány již na podzim 1919, před plánovaným rozpuštěním pluků Stráže svobody, udělily členům domácího vojska označeným jako dobrovolníci ${ }^{9}$ podobná privilegia při získávání míst státních zaměstnanců, která náležela legionářuom. Tento příkaz se však nedočkal otištění ve Věstníku Ministerstva národní obrany, proto nevešel v širší známost a značná část dobrovolníků se svých práv nedomáhala. ${ }^{10}$

Třetí skupinu vojáků nové republiky tvoří československá domobrana z Itálie. Jedná se o masu o síle 60 tisíc mužů, kteří se ocitli na konci první světové války v italských zajateckých táborech (nejvíce jich padlo do zajetí při poslední italské ofenzivě, když už se rakouské frontové linie prakticky hroutily). ${ }^{11}$ Italské velení poskytlo čs. domobrancům stejnokroje,

1920). Jinočany 1996; Fic, Victor M. : Československé legie v Rusku a boj za vznik Československa 1914-1918. I. -IV. díl. Praha 2006-2014; Československé legie 1914-1920. Katalog k výstavám Československé obce legionářské. Ed. M. Mojžíšs. Praha 2017.

6 Zákon č. 462/1919 Sb.

7 Více např́klad Lexa, Lukáš: Vojáci Slovácké brigády očima historické statistiky. Magisterská oborová práce. Brno 2018.

8 Více Ježek, Zdeněk: Účast dobrovolnikův bojich o Slovensko a Těšinsko v letech 1918-1919. Praha 1937.

9 Nemuseli vykonávat povinnou vojenskou službu. Sít národních výborů i vojenských velitelství totiž musela na nastalou situaci reagovat povoláním některých ročníků záloh. Jednalo se tedy zejména o enormně mladé muže (14-18 let) nebo naopak starší vojáky. Př́ípadně se za dobrovolnickou službu označovaly dny (někdy jen několik málo dní) od doby, kdy se muži dobrovolně přihlásili, do dne oficiální mobilizace jejich ročníku.

10 Jedná se o výnos Ministerstva národní obrany číslo jednací 37786 org. z 22. října 1919.

11 Solpera, Jan: Československá Druhá armáda. I, Příběh 56 praporů Československé domobrany z Itálie. 


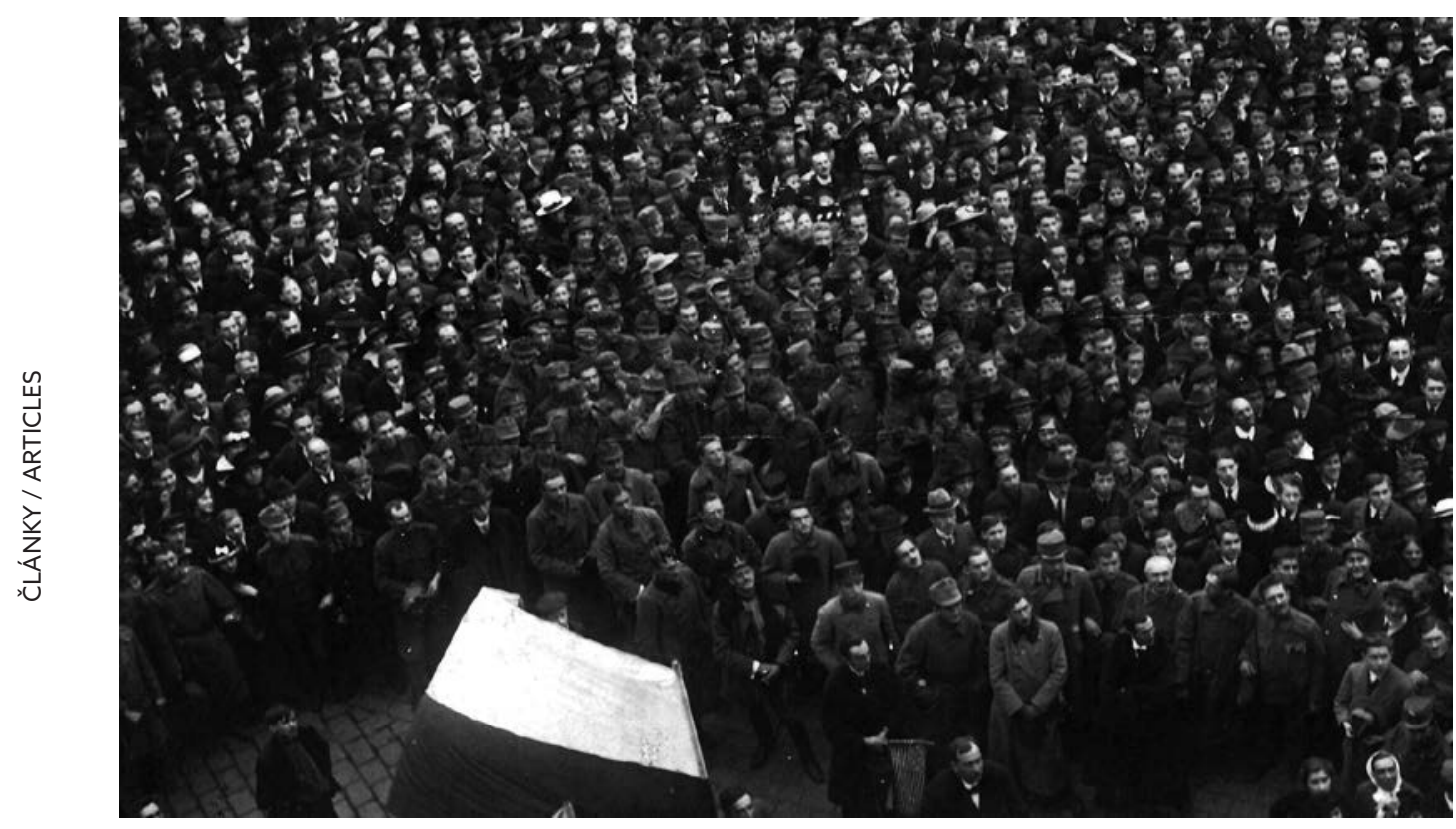

Na snímku z doby vyhlášení Československa jsou hojně viditelní muži ve vojenských stejnokrojích skomírající rakousko-uherské monarchie (sbírka autora).

ubikace a výcvik. Před odjezdem do vlasti (na jaře 1919) byli vyzbrojeni a vystrojeni z kořistních rakouských zásob. Přijížděli do Československa, aby nahradili vyčerpané a místy demoralizované jednotky domácího vojska při střežení státních hranic, německojazyčného území českých zemí a část se ocitla také v bojích na Slovensku. V této složce rodící se čs. armády bychom našli také zástupce národnostních menšin (mimo jiné českých Němců).

\section{Období hledání identit (1918-1920)}

Vyhlášení Československa provázely v lokalitách s českou většinou živelné oslavy. Kromě vzniku samostatného státu se slavil také konec nejstrašnější války v dějinách. Na ulicích se objevily davy jásajících obyvatel, ale vyskytly se i negativní projevy změny režimu. Někteří jedinci nebo skupiny obyvatel se chovali nedůstojným způsobem. Docházelo k napadání a ničení majetků Židů a německy mluvících obyvatel. ${ }^{12}$ Když pohlédneme na snímky z Prahy, Brna i dalších měst, najdeme na nich téměř vždy muže ve vojenských stejnokrojích. Nejednalo se sice o ceremonie vojenského rázu, ale přesto se vojáci stali

České Budějovice 2014; Týž: Československá Druhá armáda. II, Historie jednotlivých praporů Československé domobrany z Itálie. České Budějovice 2014.

12 Fišer, Zdeněk: Posledni pogrom. Události v Holešově ve dnech 3. a 4. prosince 1918 a jejich historické pozadí. Kojetín 1996; Lexa, Lukáš: Vznik Československa a Slovácká brigáda ve Strážnici. In: Okolo Strážnice. Strážnice 2019, s. 120-165. 


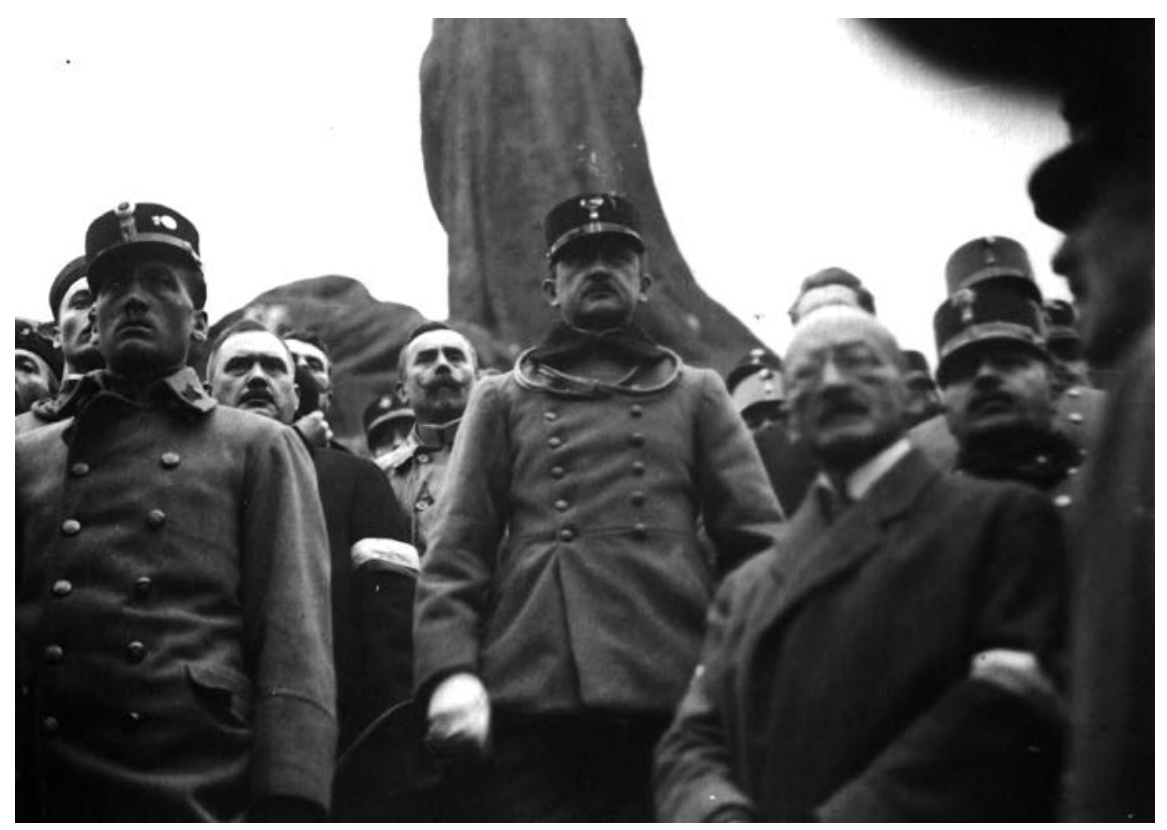

Setník Jaroslav Rošický (uprostřed) na fotografii z vojenské přísahy

v Praze na Staroměstském náměstí, za ním stojí Josef Scheiner - starosta Sokola a první vojenský velitel domácího vojska (sbírka autora).

nedílnou součástí těchto prvních oslavných aktů, at jako oslavenci, nebo jako udržovatelé veřejného pořádku.

Mezi první skutečně vojenské ceremonie nové (nebo spíše rodící se) československé armády patřily slavnostní přísahy republice (8. listopadu 1918 se uskutečnila slavnostní přísaha na Staroměstském náměstí v Praze, 17. listopadu 1918 přísahala v Hodoníně Slovácká brigáda, 18. listopadu 1918 v Uherském Hradišti Slovácký prapor, 21. prosince 1918 se přísahalo v Kroměříži atd. ). Velmi záhy po převratu si Pražané připomínali porážku stavovského povstání na Bílé hoře (8. listopadu). Říjnové události se při této příležitosti zasazovaly do kontextu národních dějin Jiráskova pojetí - čs. legionáři svým přispěním ke vzniku samostatného státu odplatili Rakousku (Habsburkům) Bílou horu a následující „dobu temna“. ${ }^{13}$

Nejsilnější pozici si mezi svátky československé armády na počátku meziválečného období uzurpovaly oslavy 28. ř́ína. „Narozeniny republiky“ se zpravidla oslavovaly v pietnějším duchu - blížil se svátek zesnulých, takže se vzpomínalo na oběti boje za samostatnost. Zvláště v prvních poválečných letech byly vzpomínky na padlé a zemřelé nejbližší ještě velmi bolestné. Při této příležitosti se pořádaly přednášky a sbírky pro vdovy a sirotky po padlých. Důležitou součástí vojenské vzpomínkové kultury se stalo právě

13 Bouček, Antonín: Bílá Hora a 28. řijen. Úpadek a politické vzkř́šsení. Praha 1919; Krofta, Kamil: Bílá Hora. Praha 1918. 


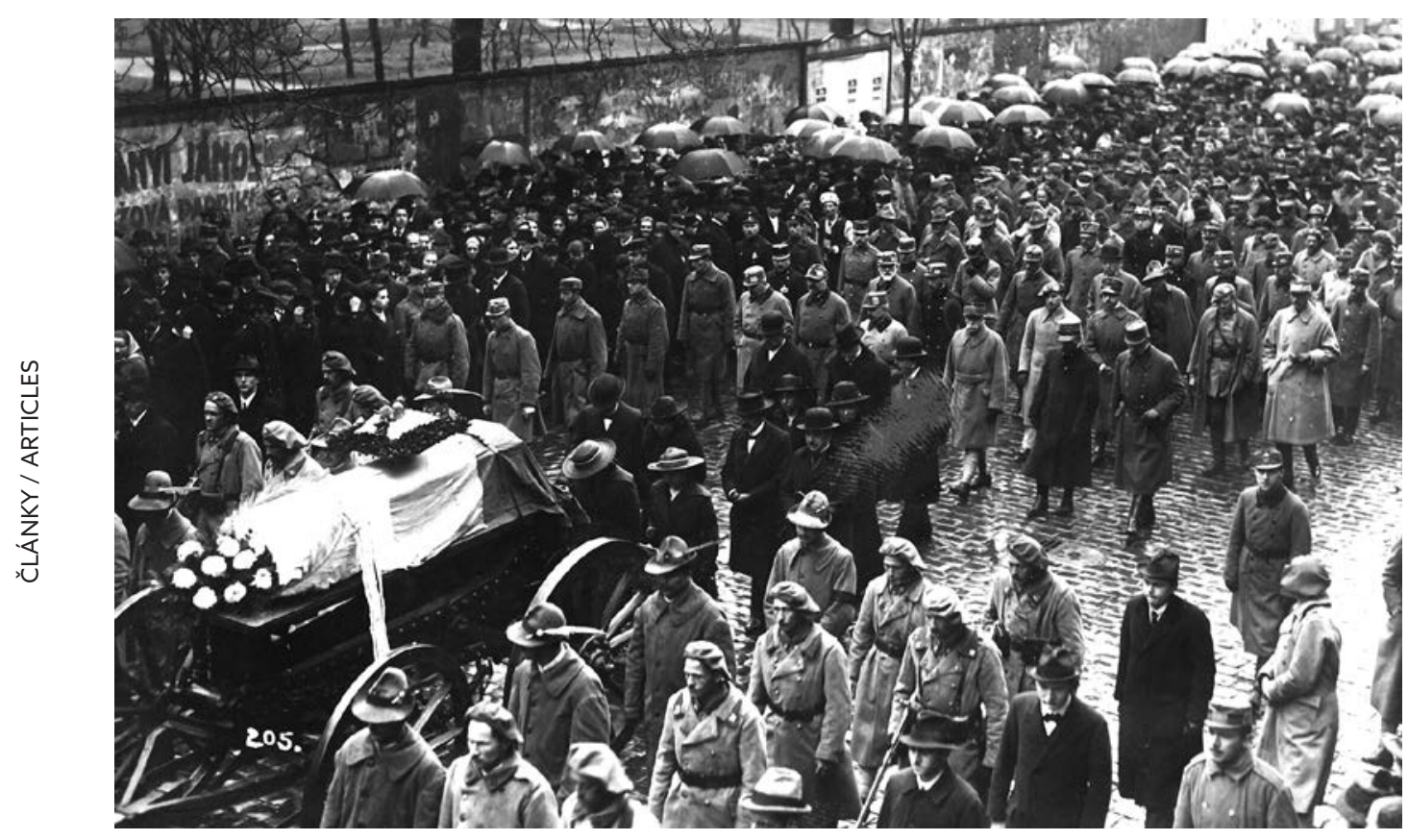

Záběry pohřebního průvodu zachycují legionáře pochodujicí na čestném místě podél lafety s rakví, zatímco muži domácího vojska jsou hojně zastoupení v samotném smutečním průvodu (sbírka autora).

vzpomínání na padlé spolubojovníky. Jejich pohřby, př́ípadně uložení jejich převezených ostatků byly monstrózními akcemi. Takto se např́klad 29. dubna 1919 na Olšanských hřbitovech uskutečnil pohřeb popraveného legionáře Josefa Sobotky za účasti ministra národní obrany Klofáče. ${ }^{14}$

Ke specifickému druhu oslav, který neměl výhradně vojenský podtext, ale souvisel s čs. státností, patřilo sázení lip svobody. Již 13. března 1919 vyzýval časopis Bratrství vojenské posádky k účasti na těchto akcích a zajištění všestranné pomoci. ${ }^{15} \mathrm{~V}$ německojazyčných oblastech měly tyto akce reprezentovat sílu české menšiny. Dne 13. dubna 1919 spojili příslušníci čs. dragounského pluku č. 2 v Dobřanech sázení Lípy svobody s oslavami 1. výročí Národní přísahy českých spisovatelů. ${ }^{16}$ Ve Strážnici se sázení lip republiky spojilo s oslavami svátku 1. máje. Zakrátko se však ozvaly kritické hlasy poukazující na neutěšený stav vysázených lip: „Lipy se ujaly, z jara zazelenaly a - a dost. Vic si jich nikdo namnoze nevšiml. Fábory, jimiž o slavnosti byly ověšeny, visi zatím opelichané, vybledlé, opršelé,

14 Bratrstvi 1, č. 21, 1. 5. 1919, s. 3-4.

15 Tamtéž, č. 14, 13. 3. 1919, s. 3.

16 Tamtéž, č. 21, 1. 5. 1919, 3-4. 


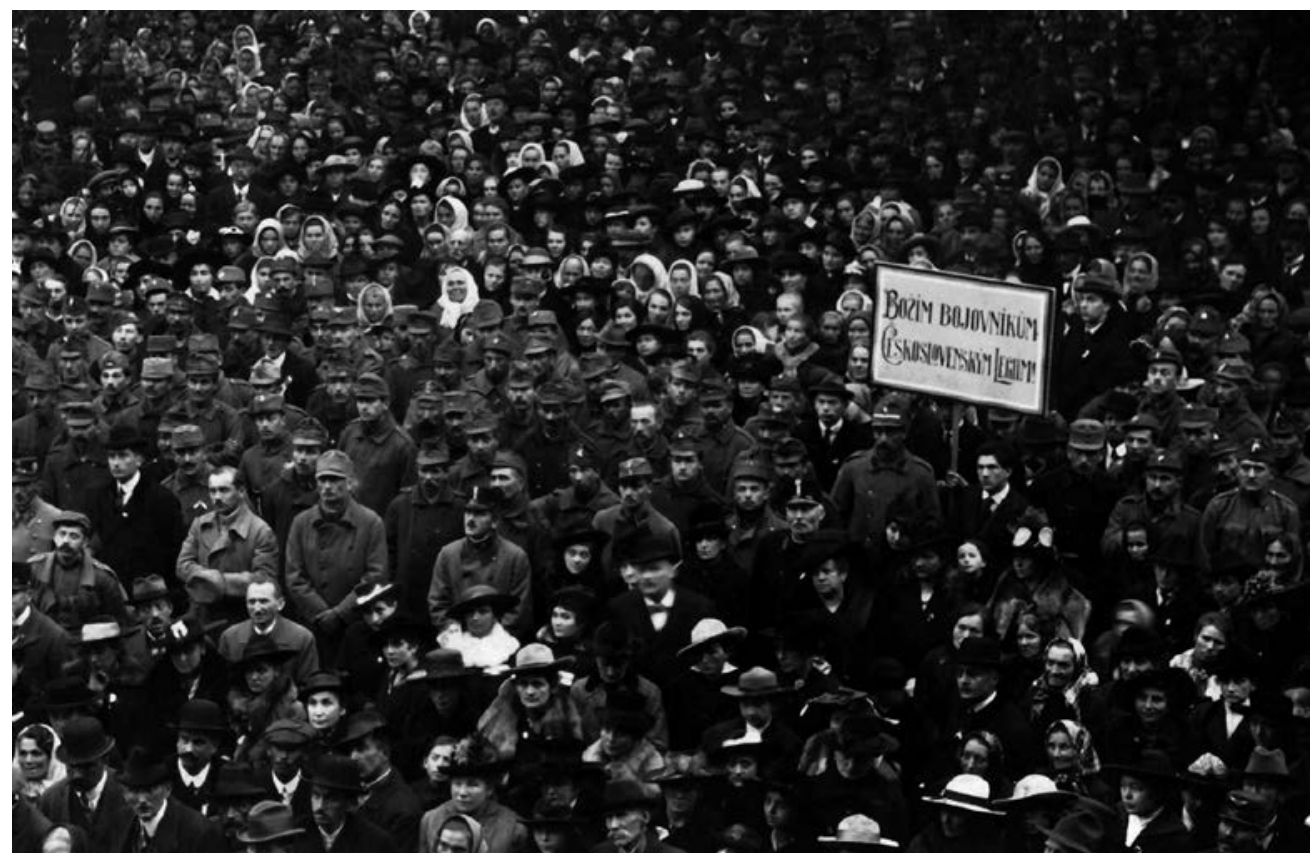

Dobová fotografie zobrazuje spontánní poděkování vlastenců československým legionářum (sbírka autora).

schumlané - slovem ohyzdné. Kmeny stoji mnohde šikmo nakloněné, ježto pưda se ssedla a stromek vychýlila z pưvodni polohy; jinde je již stromek zlomyslniky poškozen, kozami ohlodán! "17

\section{Hus kontra Zborov}

Jednou z klíčových vojenských ceremonií roku 1919 se staly Husovy oslavy. Bratrstvi již v květnu vyzývalo velitele vojenských posádek k okázalým oslavám tohoto významného dne: „Husův národ poprvé v osvobozené vlasti přistoupi k uctěni mučednické smrti velkého syna M. Jana Husa. V roce 1915 bylo našemu národu zabráněno důstojně oslaviti 500letou památku jeho upáleni 6. července v Kostnici. To musime všichni napraviti letos, a proto necht'v každém městě slouči se již dnes všechny pokrokové vrstvy a predni kulturni spolky $k$ zvláštnímu poradnímu sboru pro letošni di̊stojnou oslavu M. Jana Husa. ... Nesmíme se omeziti jen na páleni hranic, musime všude pořádati přednášky o Husovi a celé době husitské (Hus, Žižka, Jeroným, Prokop Holý a j. ) a kde to možno! akademie, př́stupné našim vojinům, musime všude rozšiřrovati dobré brožury poučujicí lid o významu a životě tohoto národního světce (sic!). Světlo budiž zažehnuto tam, kde tma a lež!"18

17 Bratrstvi 2, č. 19, 4. 3. 1920, s. 2-3.

18 Bratrstvi 1, č. 25, 29. 5. 1919, s. 2. 


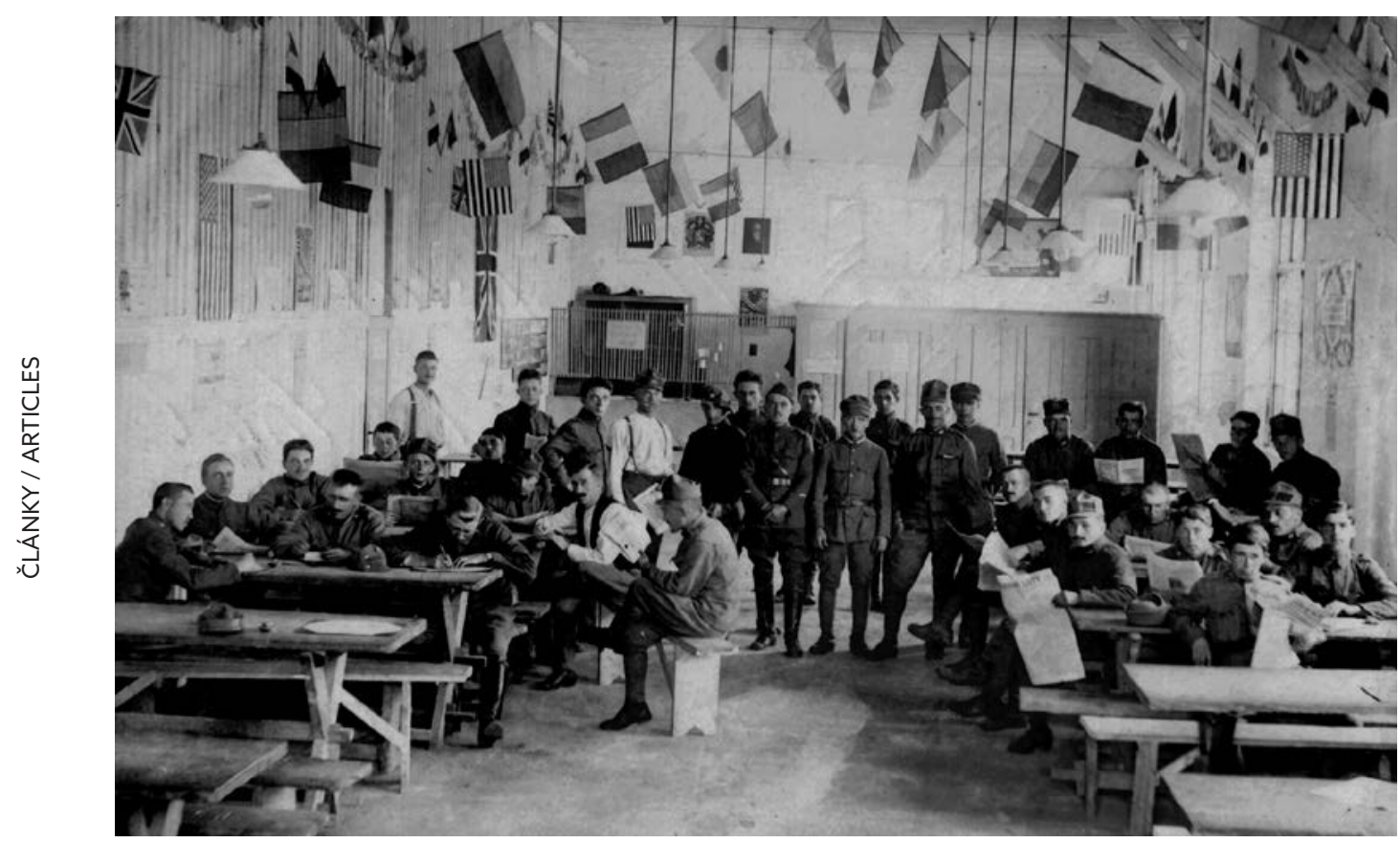

Snímek ze společenské místnosti určené k výchově, vzdělávání a zábavě vojáků (sbírka autora).

Blízkost dat výročí bitvy u Zborova (2. července) a upálení Jana Husa (6. července) nabízelo propojení těchto oslav. V roce 1919 naplno zvítězil Hus. Zborovská legenda ještě nebyla natolik rozšířená. Ruští legionáři prozatím brázdili Sibiř a ve vlasti se jich nacházela jen hrstka. Titulní list Bratrství z 3. července 1919 přináší 4 články věnované Husovi, zatímco Zborov je zmíněn pouze na okraji „vpravo dole“. Ovšem i článek o Zborovu je úzce spojený s tématikou Husova svátku. I v roce 1920 jednoznačně převládaly Husovy oslavy nad připomínkou bitvy u Zborova. ${ }^{19} \mathrm{~K}$ obratu dochází teprve v roce 1921 po návratu zbytku čs. legionářů z Ruska, kdy na stranách Bratrstvi vítězí Zborov. ${ }^{20}$

\section{Ideové podhoubí vojenských festivit}

Denní tisk od prvního momentu existence republiky zásoboval obyvatelstvo informacemi o hrdinských činech československých legionářů a snad se tím snažil splatit dluh vzniklý za Rakouska-Uherska. Jako ryze armádní periodikum můžeme označit Bratrství. První číslo vyšlo 12. prosince 1918. Právě na jeho stránkách najdeme přehled myšlenek, které mohly podněcovat vývoj vzpomínkové kultury. Kvůli snaze o upevnění kázně domácího 
vojska se vystavovaly do popředí idealizované příběhy z dějin legionářského hnutí. Tento fenomén však nepocházel přímo z iniciativy legionářů, ale sahali k němu i důstojníci monarchie přjejatí do čs. armády. ${ }^{21}$

Jedna z klíčových myšlenek, která se měla aplikovat u domácího vojska, vychází ze samotného názvu periodika - tedy bratrství. Sokol Karel Vaníček stavěl bratrství v souladu s Jiráskovým narativem do souvislosti s husitským hnutím, zatímco do protikladu postavil žoldnéřství a otrokářství Němců. V prvních momentech se objevovaly idealistické tendence změnit armádní duch na bratrský a otevřenější, omezující vojenské autority, což se velmi záhy ukázalo jako zavrženíhodné, stejně jako myšlenka na transformaci pravidelné armády na milici. U domácího vojska se tedy neaplikovalo tykání vojínů vyšším hodnostářům ani legionářské opěvované bratrství. V dané situaci však nelze hodnotit toto rozhodnutí vojenských orgánů negativně. ${ }^{22}$

Problémy s kázní vojska byly v poválečné době všeobecným zjevem minimálně ve střední a východní Evropě. Pro upevnění morálky vojáků sahali jejich nadřízení nejen k represivním opatřením, ale zvláště k posílení výchovy. Konaly se přednášky, společenské akce a vojenské ceremonie. Tyto se mnohdy pojily s tělovýchovnými přebory ve stylu sokolských cvičení a regionálních sletů. Kupřríkladu 14. střelecký pluk uspořádal ve vojenském táboře na Mušlově (nedaleko Mikulova) oslavy 1. máje v duchu sokolských závodů. ${ }^{23}$ Podobně v Josefově oslavili 1 . máj mimo jiné zápasem v kopané. ${ }^{24}$

Vyzdvihování hrdinných příkladů legionářů přinášelo ovoce v podobě kladně působícího povzbuzení pro vojáky domácího vojska nebo italské domobrany, avšak stále více to rozevíralo pomyslné nůžky mezi legionáři a nelegionáři. Jako základní pilî̌re vzpomínkové kultury československé armády mezi dvěma světovými válkami můžeme označit národní historii, sokolské hnutí a legionářské hnutí. Všechny tři měly posilovat československé národní sebevědomí. Člen německé, mad’arské, polské nebo židovské menšiny by v nich hledal zalíbení jen stěží.

21 Zde můžeme zmínit spontánní přihlášení se k legionářskému hnutí velitelem Slovácké brigády setníkem dělostřelectva rakousko-uherské armády Cyrilem Hluchým: „Doufáme, že spojenecká vojska a naše drahé čsl. legie co nejdř́ve přijdou, aby nám pomohly, ale do té doby je na nás, abychom si sami udrželi pořádek. Dokažme, že jsme hodni svobody, kterou oni nám vybojovali, že jsme s to svobodu tuto sami obhájiti. Bylo by největši potupou pro nás a uvalilo by to na nás nové starosti o chléb, kdybychom musili na pomoc proti sobě samým povolávat vojska spojenců. Duch legii i dále pěstěn a žíti bude v naši Slovácké brigádě. Jen právo a svobodu chceme hájiti. A s heslem tím možno jen zvitěziti nebo zemříti. Slovácká brigáda tvořiti chce most, který spojovati má světovou slávu československých legii se skvělou budoucností národní. " - Vojenský ústřední archiv v Praze / Vojenský historický archiv (=VHA Praha). f. Slovácká brigáda, kart. 1, inv. č. 7, Brigádní rozkaz č. 1.

22 Dva roky bojů a organizačni práce. Československá armáda v letech 1918-1920. Edd. Břach, Radko - Láník, Jaroslav. Praha 2013; Kalhous, Rudolf: Budováni armády. Praha 1936.

23 Bratrstvi 1, č. 23, 15. 5. 1919, s. 3.

24 Tamtéž, č. 24, 22. 5. 1919, s. 2. 


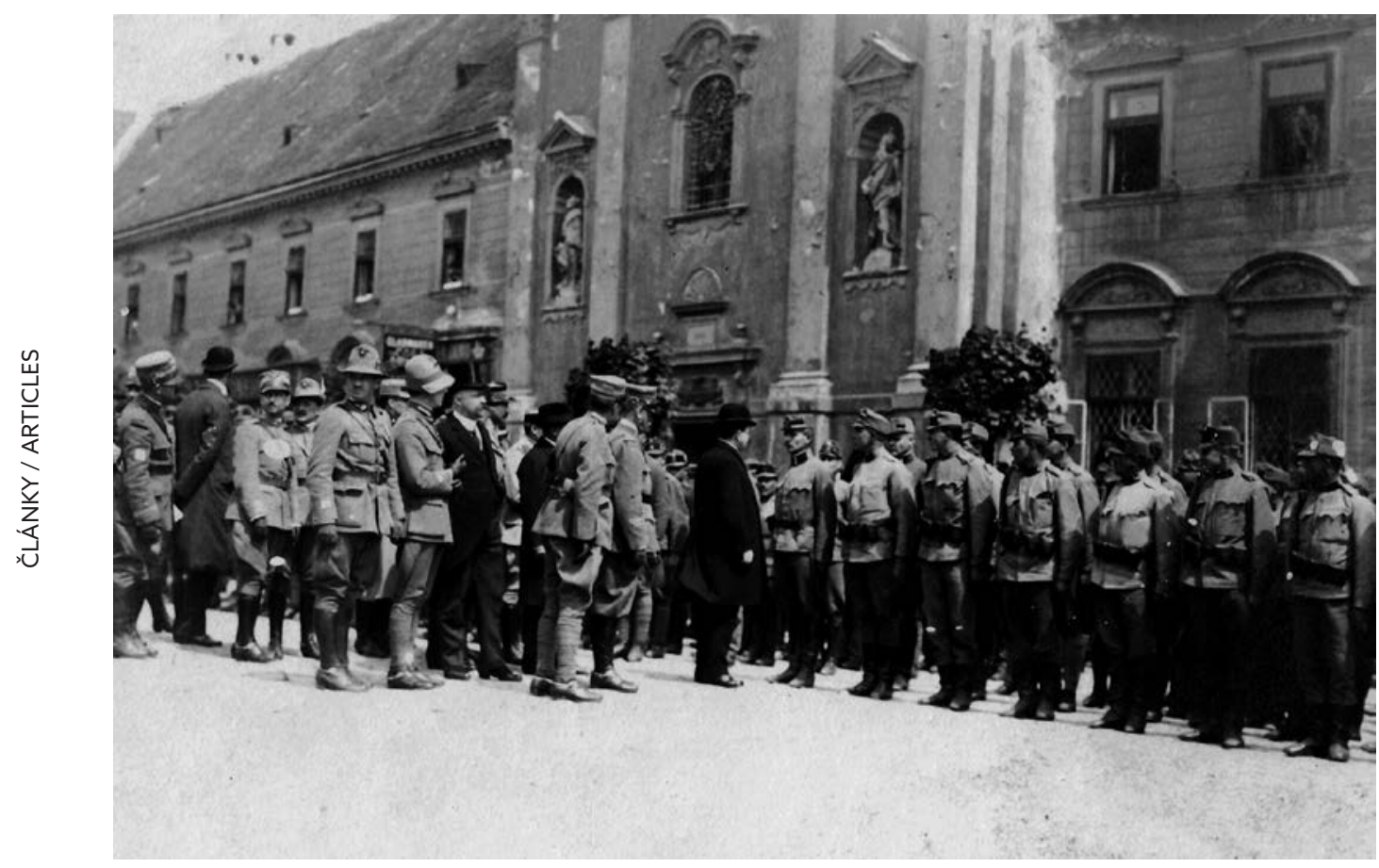

Vojenská ceremonie v Bratislavě s účastí italské vojenské mise a ministra národní obrany Václava Klofáče (sbírka autora).

\section{Kritika množství a formy oslav}

Po převratu se začaly slavit narozeniny T. G. Masaryka (7. března), které zaujaly jedno z předních míst mezi státními svátky. V roce 1919 můžeme na oslavách narozenin prezidenta v Litomyšli a Brně demonstrovat kontrast mezi dvěma způsoby forem ceremonií. Zatímco Litomyšl se postarala o skromné, avšak důstojné oslavy bez vojenských parád, Brno kráčelo „rakousko-uherskou“ cestou a spojilo oslavy s mohutnými vojenskými poctami (vojenská přehlídka a výstřel salvy z děl umístěných na Špilberku). ${ }^{25} \mathrm{Na}$ kontinuitu podoby oslav s předcházejícím režimem se snesla vlna kritiky: „Vojenské slavnosti rakouské bývaly parádami, jež dovedly prívábiti jen lidi nemyslící. Nic nás při nich nevzrušilo a ač bychom byli často rádi dali na sebe pưsobiti rytmem a mohutnosti pohybujicich se kolon, či veselou melodii hudby odvraceli jsme se, nebot - to v̌se bylo cizí, neprátelské, nemajicí s národním životem a cítěním pranic společného. "26 Okázalost vojenských defilé, čepobití (slavnostní troubení večerky) a jiných vojenských ceremoniálů byla často odsuzována, přesto tyto prvky nevymizely ani z prvorepublikové armády. Okázalost a odosobnění bylo v československém prostředí rozředěno množstvím přednášek a citových prvků působících na národní sebevědomí. 
Současníci poukazovali i na př́lišnou početnost festivit. Armáda slavila vedle oficiálních svátků také výročí významných bitev, výročí založení vojenských jednotek (zejména legionářských) nebo narozeniny osobností vojenského života (29. února 1920 se v Josefově uskutečnily oslavy narozenin generálního inspektora čs. armády Josefa Svatopluka Machara). ${ }^{27}$ Kritika se dostala i na stránky Bratrstvi: „Všechny vrstvy národa svorně, jakoby chtěly zapomenouti na v̌sechnu bídu, morálni i fysickou vyhledávaji pobavení. Biografy, divadla, kabarety naplněny do posledního mistečka a lidé se baví, utrácejice vesele nestarajice se o zítřek. [...] Celá veřejnost se pachtí předvésti očím cizinců svéráz našeho života, což mnohdy konč fiaskem. [...] Naše vláda ve snaze vybřednouti z neurovnaných poměrů chce tak učiniti vývozem našich výrobků, čímž podporoval by se vzrůst hodnoty naši měny. K tomu cíli jest nutno, aby národ ustal již ve suých šilených oslavách ničeho. [...] U nás jest dosud nouze o suroviny, neni uhlí, a vyvážet by se mělo a tak přece snad dojde na slova onoho pražského obchodnika, který dívaje se na jednou podařený průvod řekl: co se vývozu týče, myslím že budeme moci v brzku exportovati do ciziny, ale nikoliv naše výrobky, spiše slavnosti. “28

Nová politická orientace a spojenecké vazby na země Dohody přinesly i nové svátky zahraničního rázu. 24. května 1919 se v Bratislavě konala okázalá slavnost 4. výročí vstupu Itálie do války a uznání čs. požadavků na vytvoření legií. ${ }^{29} \mathrm{~V}$ této době ještě v Československu působila italská vojenské mise v čele s generálem Luigim Piccionem. Mohlo se jednat o snahu zalíbit se italskému spojenci nebo přímou výzvu Italů k této ceremonii? Po vystřídání italské vojenské mise francouzskou se již zmínky o oslavách tohoto svátku neobjevují. Naopak 14. července 1919 byl oslaven francouzský státní svátek pádu Bastilly. ${ }^{30} \mathrm{Na}$ kasárna se tehdy vyvěšovaly československé a francouzské vlajky. 4. července se slavil také svátek „osvobození států severoamerických“ (Den nezávislosti) a 21. července belgický národní svátek (př́ísaha krále Leopolda I. ). ${ }^{31}$ Lze se tedy domnívat, že zahraniční vojenské mise nepřímo ovlivnily, co budou vojáci oslavovat. Období protkané radostí, ale i mnoha starostmi muselo ustoupit době stabilizace státu. S ní se vytrácely i některé festivity, které lze spatřit v prvních letech Československa.

\section{Léta stabilizace (1921-1935)}

V průběhu dvacátých let se situace armádní komemorace ustálila. Jako základní periodický triptych, který dělily i poměrně rovnoměrné časové odstupy, se ustavily oslavy 28. ř́jjna, Zborovské oslavy a oslavy narozenin prezidenta T. G. Masaryka. Vedle těchto tří základních akcí se uskutečňovaly výběrové ceremonie vážící se ke specifickým výročím vojenského i civilního světa (např. oslavy výročí založení pluků). S ohledem na vnucené oslavy za dob Rakouska-Uherska se prvorepubliková státní moc uchylovala s pozvolnému

27 Bratrstvi 2, č. 20, 11. 3. 1920, s. 4.

28 Bratrstui 1, č. 43, 2. 10. 1919, s. 2-3.

29 Tamtéž, č. 26, 5. 6. 1919, s. 2.

30 VHA Praha, f. Slovácká brigáda, kart. 16, inv. č. 1023, Deník V. polního praporu; Bratrstvi 1, č. 37, 21. 8. 1919, s. 4; VHA Praha, f. 27. pěší pluk, Kronika z let 1918-1921.

31 VHA Praha, f. 5. hraničářský prapor, Kronika 2. roty 5. hraničářského praporu. 


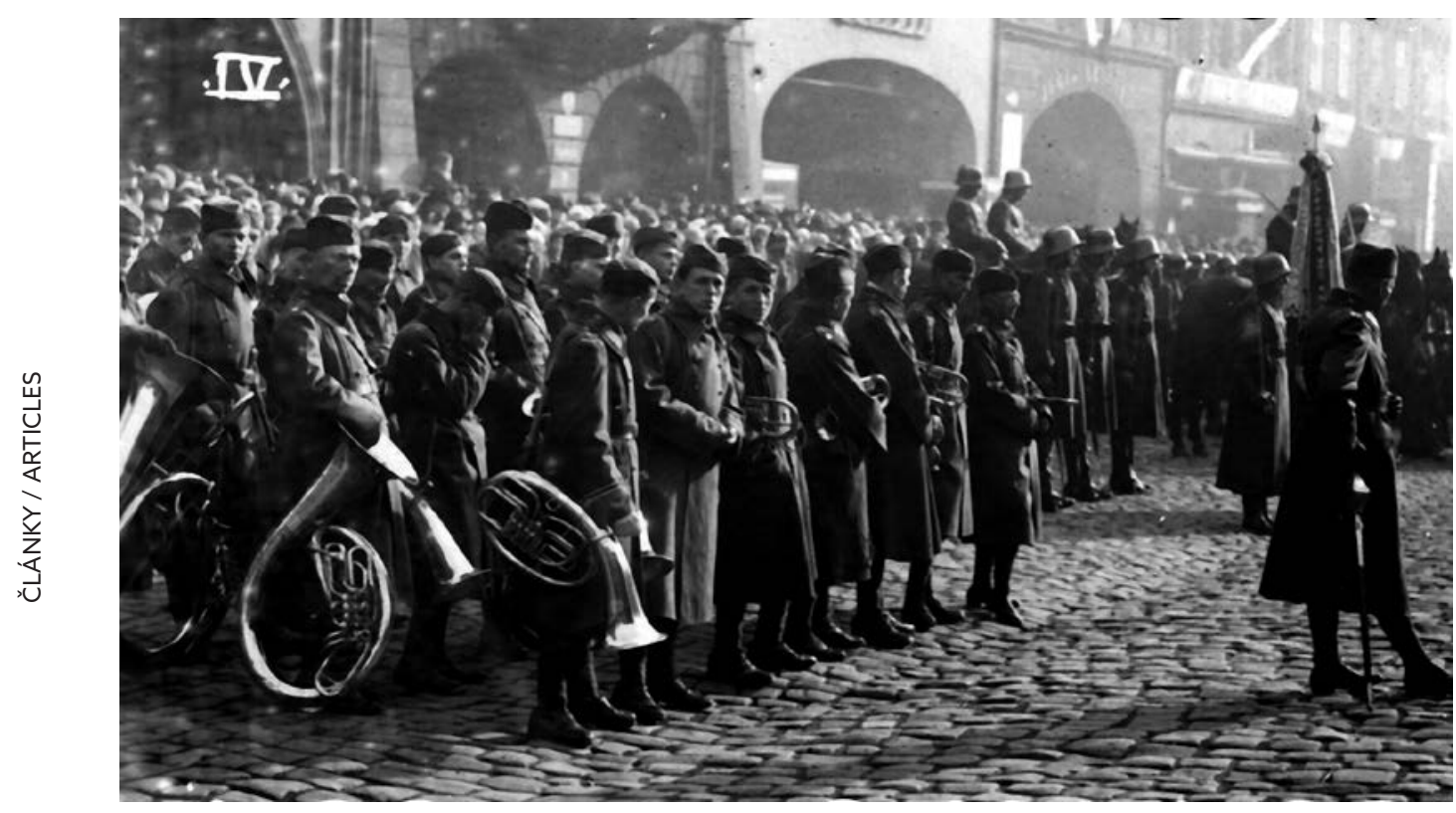

Momentka z vojenské ceremonie z 20. let zachycuje vojenskou hudbu, která se stala jedním z hlavních prvků „zapůjčovaných" armádou pořadatelưm nejrůznějších oslav k dodání důstojnosti celému aktu (sbírka autora).

nenucenému prosazování svátkového kalendáře. ${ }^{32}$ Ministerstva vydávala pokyny, jak mají být oslavy připravovány a „celebrovány“. Nikde však nespatřujeme nátlak na provádění oslav. Postih hrozil spíše za nedůstojné provedení ceremonie nebo její narušení. V národnostně smíšených oblastech hráli prim v prosazování československé státnosti čeští úředníci nebo vojenští představitelé. Mnohde však tento fakt zvětšoval třecí plochy mezi národnostními skupinami. ${ }^{33}$

Při formování svátkového kalendáře převážila legionářská koncepce. Zásluhy domácího vojska byly upozaděny a vzplály i spory o zásluhy civilního odboje (Masaryk a Beneš kontra Kramář a Stř́ibrný). Po ustálení poměrů v novém státě získávaly silnou pozici svátky z hnutí čs. legií v Itálii a Francii (bitva u Terronu, Vouziers, Arrasu nebo na Doss Alto). ${ }^{34}$ Tyto oslavy však záhy, jak jsme ukázali výše, převrstvila legenda jménem Zborov. Postupně se z ní stal hlavní armádní svátek, což podpořilo vícero faktorů. Jednalo se o první skutečně pospolité vystoupení čs. legionářů v Rusku, navíc vítězné. Československé legie v Rusku byly nejpočetnější, takže měly největší sílu se prosadit, a navíc se svátek mohl slavit v př́ijemném ročním období - létě. ${ }^{35}$ Svátek 28 . října s obvykle již deštivým

32 Sláva republice!, s. 150.

33 Například při oslavách v Šazích v roce 1923. Sláva republice!, s. 105.

34 Bratrství 4, č. 52, 19. 10. 1922, s. 4; Bratrství 3, č. 52, 20. 10. 1921, s. 1.

35 „Náš 28. řijen svou ročni tesknou pohodou a připomínkou všech obětí boje za svobodu, již vzniká jeho nálada, nemůže býti naším dnem jásavého veseli nad vítězstvím, jak si jej vytvořili Francouzové ve svém dnu pádu Bastily nebo 


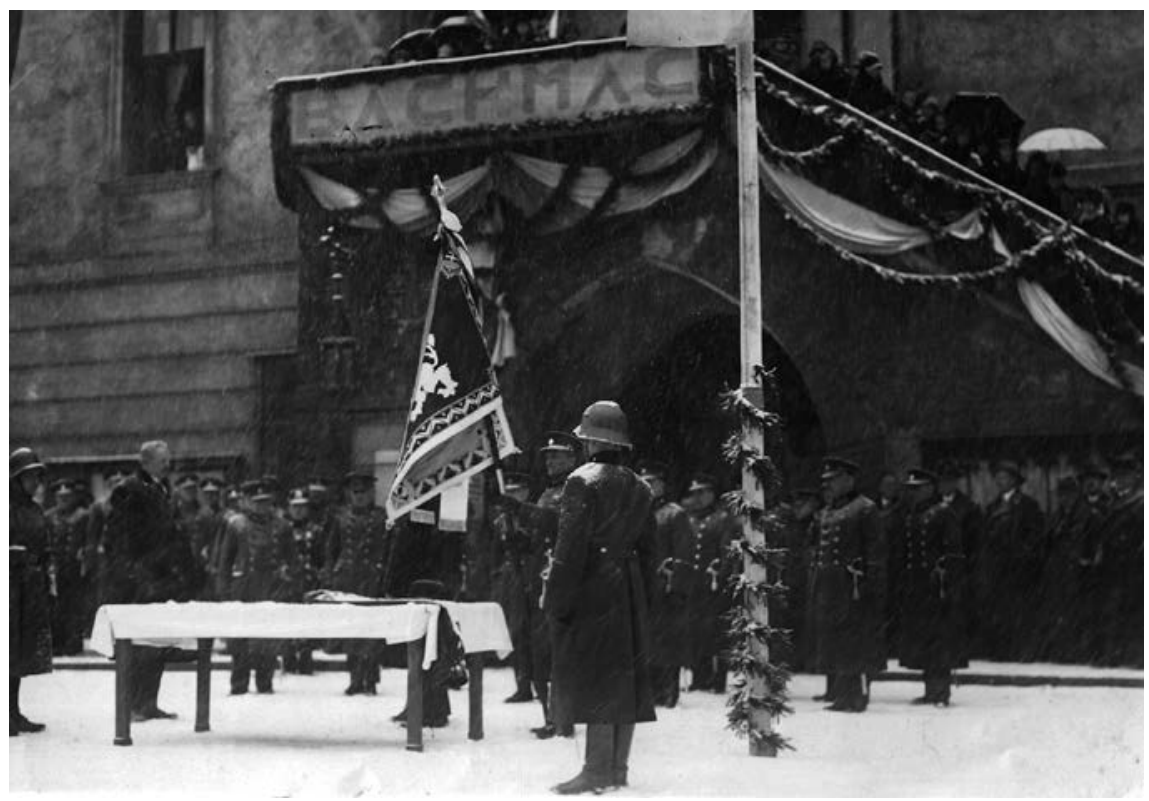

Ukázka další z oslavovaných bitev čs. legií v Rusku - 10. výročí bitvy u Bachmače v Olomouci (sbírka autora).

a chladným počasím evokoval náladu tryzny, zatímco červencové výročí Zborova svádělo k opravdovým oslavám. Přestože výročí vycházelo na 2. července, podařilo se do něj zapojit i školní mládež. Různé akce zaměřené na žactvo (k nejznámějším patří Zborovský závod branné zdatnosti) se konaly již v průběhu června, na konci školního roku. Nemělo by zůstat bez povšimnutí, že i pluk navazující na italské tradice (32. pěší pluk v Košicích) raději zvolil pro slavnostní ceremonii předání praporu datum bitvy u Zborova. ${ }^{36}$ Není to však pravidlem. Turnovský 44. pěší pluk obdržel prapor v den narozenin T. G. Masaryka. $^{37}$

Zdaleka nejokázalejší slavností daného období se staly oslavy desetiletého výročí republiky v roce 1928. ${ }^{38}$ Provázelo je množství různých ceremonií. V menším městě Hodoníně vojenská posádka v tento den vykonala slavnostní přísahu, v kasárnách byla odhalena busta T. G. Masaryka a došlo ke slavnostnímu poklepání na základní kámen pomníku T. G. Masaryka a legionářo̊. Ve výběru oslavovaných dějinných událostí a osobností vítězili hrdinové Jiráskova pojetí národní dějin. V ř́ínu 1924 se na mnoha místech uskutečnila shromáždění u př́iležitosti 500. výročí úmrtí Jana Žižky (např. v Josefově, Milovicích

Američané ve svém Dnu nezávislosti. Chceme mít svůj vítězný den v blizkosti památky Zborova, slunného vítězství, jež pripomíná a zobrazuje v̌̌echna naše vítězstvi na polich ducha i krve, doma $i$ za hranicemi, která prípravila dnešek. Tedy nejen den odboje, ale více a raději Den vitězný. “Moravský legionář 6, č. 24, 10. 6. 1926, s. 3.

Bratrstvi 9, č. 44, 28. 7. 1927.

37 Bratrství 8, č. 31, 29. 4. 1926.

Sláva republice!, s. 75-136. 


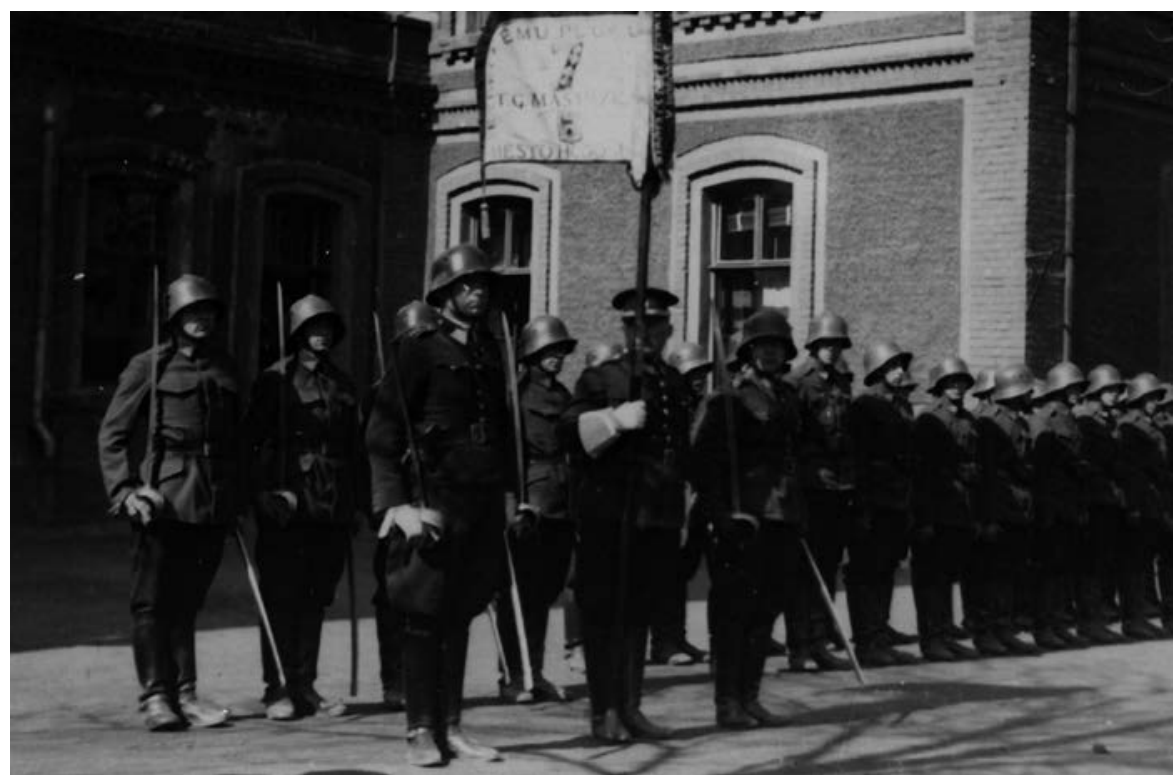

Dragouni od 7. jezdeckého pluku T. G. Masaryka v Hodoníně s plukovní standartou (sbírka autora)

nebo Brně). ${ }^{39}$ Patřičné pozornosti se dostávalo i českému patronu svatému Václavovi. Jednalo se však o spíše církevní svátek, kterého se účastnilo zejména civilní obyvatelstvo a legionáři-veteráni ve svých stejnokrojích. Teprve v roce milénia Václavovy tragické smrti 28. září 1929, kdy došlo k určitému „postátněni““ oslav, se ve větší míře zúčastnila i čs. armáda. ${ }^{40} \mathrm{O}$ dva roky později byl v tomto symbolickém datu odhalen památník čs. legionářủm a T. G. Masarykovi v Hodoníně. ${ }^{41} \mathrm{U}$ armády naopak nikterak nerezonovala cyrilometodějská tradice. Zřejmě ne pouze kvůli své ryze církevní symbolice, ale také kvůli své malé bojovnosti. Vedle zmíněných svátků se nadále uskutečňovaly oslavy 1. máje. ${ }^{42}$ Byly však i události, které jejich organizátoři nepřimkli k určitému významnému datu (např̀. předání standarty 7. jezdeckému pluku T. G. Masaryka v Hodoníně 8. června 1930). ${ }^{43}$

Při oslavách 28. října hrála klíčovou roli armáda, jakožto nositelka tradic a ochránkyně republiky. Ilustruje to mimo jiné řazení lampionového průvodu z roku 1922 v Hodoníně: vojáci z povolání, čestná rota 7. jezdeckého pluku, školou povinné děti, zástupci úřadů, městská rada, spolek Hlahol, legionáři, Sokolové, ostatní spolky a občané. ${ }^{44} \mathrm{~V}$ tomto roce zde ještě nenajdeme zmínku o veteránech čs. domobrany z Itálie ani domácího voj-

39 Bratrství 7, č. 5, 20. 11. 1924.

40 Sláva republice!, s. 363, 369.

41 Státní okresní archiv (SOkA) Hodonín, f. Archiv města Hodonín, inv. č. 1325, Fotoalbum města Hodonína.

42 Bratrství 4, č. 29, 11. 5. 1922, s. 3.

43 SOkA Hodonín, f. Archiv města Hodonín, kart. 21, inv. č. 528, Pamětní kniha města Hodonína.

44 Tamtéž. 
ska. V periferních oblastech se místy dařilo vztahy narovnávat, avšak na centrální úrovni zůstávali na předních a výlučných postech legionáři. Ukázkou pomalého smiřování legionářů a nelegionářủ jsou plukovní oslavy v Kroměříži. 15. března 1921 proběhly oslavy 4. výročí založení 3. pěšího pluku (existence rakouského předchůdce nebyla takřka vůbec reflektována). ${ }^{45} \mathrm{O}$ několik let později už nalezneme alespoň kusé zmínky o příslušnících domácího vojska, kteří se ve dnech 2. -6. července 1927 po boku legionářů účastnili setkání vojáků 3. pěšího pluku.

\section{Hody svobody}

Jako modelovou událost pro srovnání vojenské slavnosti v průběhu 20. a na konci 30. let můžeme zvolit Den odboje v Břeclavi, který se uskutečnil 6. června 1926, a Manifestační sjezd brněnské župy Československé obce legionářské v Břeclavi z 5. června 1938. ${ }^{46}$ Obě pojí místo konání a zaměření akce, přesto je kromě 12 let dělí také rozdílná politická situace. Na Dni odboje se podílela hlavně Československá obec legionářská, mezi řečníky patřil její pozdější předseda a poslanec Národního shromáždění Joža David. Akce sestávala $\mathrm{z}$ přednášek v předvečer samotné akce, schůze legionářů, promenádního koncertu vojenské hudby, průvodu uniformovaných a krojovaných osob a dalších aktivit. Do průběhu akce byli zapojeni taktéž aktéři domácího odboje (oběti procesu s velezrádci z Kostic). Domácí vojsko ani činnost Slovácké brigády zmíněna nebyla.

V Moravském legionári byla otištěna obsáhlá ideová stat’ osvětlující propojení oslav vojenského rázu s civilním: „Neměl to býti jen výlet s celou obvyklou výpravou. Náš Den odboje chtěl býti svátkem Břclavska. Chtěl býti slavností, která má vnitřni obsah, svou duši, z niž bude prýštit její radostnost. Chtěl býti slavností, jež svede ve svém družném veseli všechny z kraje, kdož jsou zajedno v upřimné a vděčné vzpomince na to co - ač nedaleko - je už krásnou minulostí, na naše vitězství. Vitězstvi v osvobozovacím boji jak doma, tak za hranicemi. Tato vzpominka přece stači na radost, opravdovou, silnou, které potřebujeme jako poháru jiskřivého vína ve rmutu všednich dni. ... Co bylo nejsilnějším pocitem každého z legii, když si uvědomil sílu celku, když přišly úspěchy, když konečně přišlo vítězství, když se zase ocitl na rodné pưdě - svobodné vlastni vưli? A co bylo také nejsilnějším pocitem všech našich dobrých lidi doma na sklonku války, zejména v posledni čtvrti roku osmnáctého? Tu i tam to byla hluboká radost, celou osobnost zalévajici, ale současně i očistujici a plníci novou silou, velkou láskou, bratrstvím a krásnou hrdostí. Lidé byli lepši a silnější. Tuto radost chtěla tedy kř́sit naše slavnost, připominat ji a jeji kořeny, znovu se ji naplňovat i tou jeji mocí sílici a očistujici. Chtěla býti našimi opravdovými »hody svobody", našim »posvicenim osvobozeni巛. ${ }^{47}$

45 VHA Praha, f. 3. pěší pluk, Kronika pluku.

46 Moravský legionář 6, č. 24, 10. 6. 1926, s. 3; Národni osvobozeni 15, č. 46, 9. 6. 1938, s. 5.

47 Morauský legionár 6, č. 24, 10. 6. 1926, s. 3. 


\section{Doba sjednocování proti společnému nepříteli (1936-1938)}

Poslední etapa sledovaného období se nesla v duchu sjednocení československé společnosti v době ohrožení republiky. Teprve společný nepřítel dokázal sjednotit značnou část rozhašteřených veteránských organizací. Armáda pocítila palčivou potřebu výchovy mladých chlapců k brannosti, aby si mohli záhy při výkonu vojenské služby rychleji osvojit požadované předpisy a návyky. Právě s tím, a nepřímo tedy i s obranou státu jí mohly veteránské a polovojenské organizace pomoci. Z komorních nebo pietních oslav svátků se stávaly obrovské manifestace. K tradičnímu výše zmíněnému trojlístku 28. říjen - 2. červenec - 7. březen v posledních letech republiky přibylo velké množství oslav kulatých výročí bitev (Bachmač, Vouziers, Chestres a další), narozenin prezidenta E. Beneše a úmrtí T. G. Masaryka. Zuřící občanská válka ve Španělsku poněkud otřásla nezlomnou vírou obyvatel, že se již nebudou hrůzy „Velké války“ opakovat. Sami občané se tak mnohem více aktivizovali a nešlo jen o pokyn z vyšších míst.

Můžeme se vrátit ke srovnání dvou událostí. Na mladší z nich budeme tentokrát ilustrovat zapojení organizace dobrovolníků z let 1918-1919. Manifestační sjezd Československé obce legionářské a spolku dobrovolců v Břeclavi ve dnech 5. -6. června 1938 se stal událostí, na které se široké spektrum veteránských a branných organizací (Svaz čs. důstojnictva, Sdružení př́íslušníků bývalé Slovácké brigády, čsl. domobrana z Itálie a Národní garda 40) pokoušelo oslovit ještě širší spektrum veřejnosti než v roce $1926 .{ }^{48}$ Program byl sice plně podřízen legiím, ale v zájmu zachování celistvosti Československa se dostali ke slovu také početní dobrovolníci někdejšího domácího vojska a domobrany z Itálie. Program sjezdu zahrnoval položení kytic k pomníku T. G. Masaryka, divadelní představení Jízdni hlidka, slavnostní schůze čs. legionářů a hostů, slavnostní průvod a odhalení pamětní desky legionářum. Při manifestaci na náměstí došlo i na slib věrnosti republice, její vládě a prezidentu E. Benešovi. ${ }^{49}$

\section{Úloha dobrovolnických spolků}

Vojáci bývalého domácího vojska, členové pluků Stráže svobody, Slovácké brigády atd. mohli vedle legionářů v průběhu meziválečného období vytvářet svá zájmová uskupení. Opravdový boom zažily tyto veteránské spolky ve druhé polovině 30 . let. ${ }^{50}$ Některé fungovaly dokonce již ve 20. letech, což nabourává klišé, že v průběhu prvorepublikového Československa nemohly působit jiné než legionářské vojenské spolky. Najdeme celou řadu spolků vojenských vysloužilců a „poškozenců“. Státní aparát se bránil především proti spolkům s nacistickým (německým), fašistickým (českým) nebo komunistickým nátěrem.

Př́íslušníci popřevratového III. pluku Stráže svobody (vzniklého v Brně) se v roce

48 SOkA Břeclav se sídlem v Mikulově, f. Archiv města Břeclav, k. 37, inv. č. 307, Čs. obec legionářská 1932-1938.

49 Národni osvobozeni 15, č. 46, 9. 6. 1938, s. 5.

50 Dokládá to nárůst počtu veteránských nelegionářských organizací a periodik. Viz Indra, Jaromír: Spolky C. k. vojenských vysloužilců v Čechách, na Moravě a ve Slezsku. Vlastním nákladem 2010. 


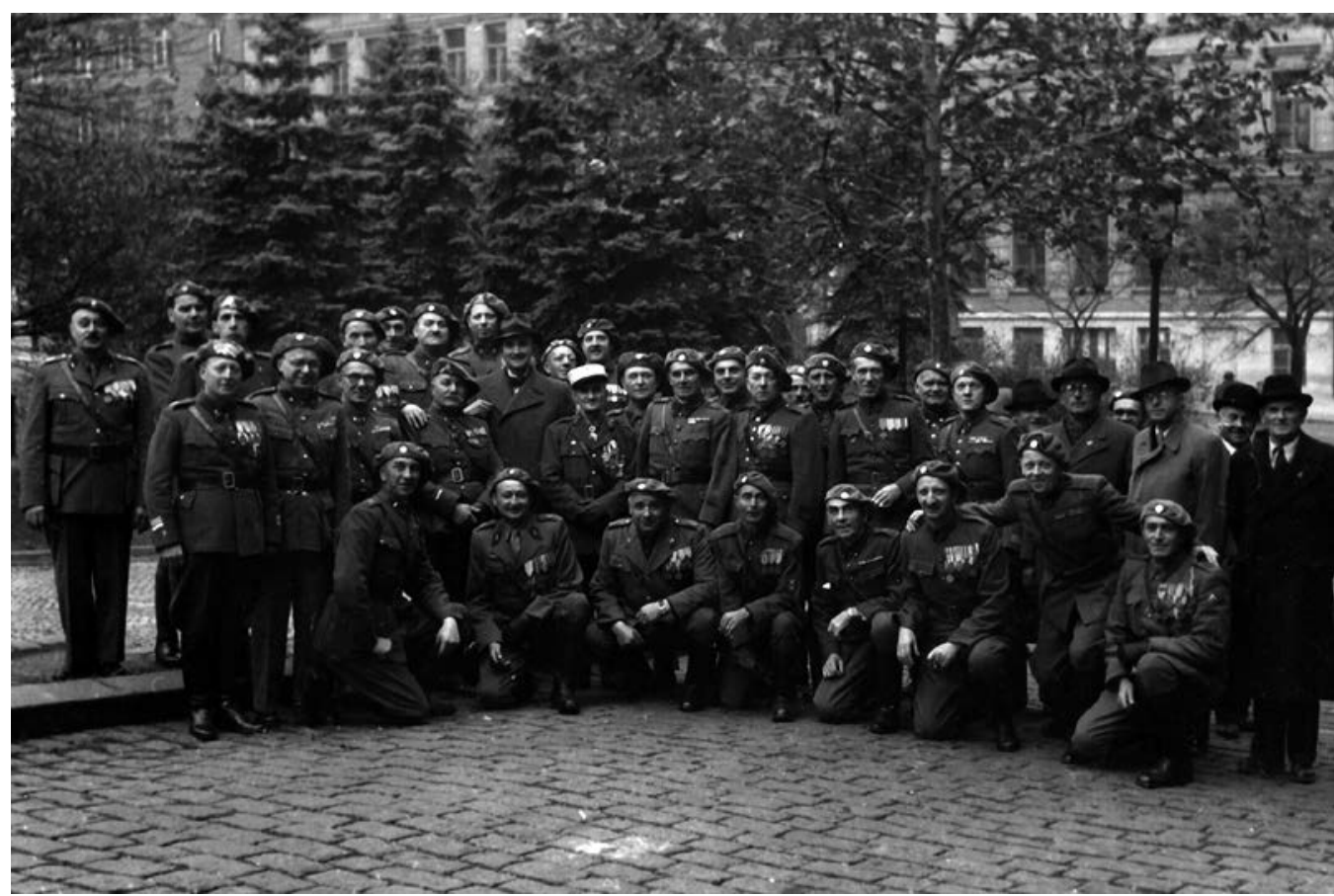

Veteráni domácího vojska na jednom ze svých setkání (sbírka autora).

1924 organizovali ve spolku Sdružení bratří bývalého pluku Svobody č. III a jejich přátel. Valná hromada tohoto spolku proběhla v září 1924. ${ }^{51}$ Jednalo se o funkční spolkovou platformu pro společné trávení času. ${ }^{52}$ Sdružení pořádalo kulturní akce (plesy, přednášky), sokolská cvičení, ale též pěší turistické vycházky v okolí Brna. Spolek informoval širší členskou základnu i veřejnost o své činnosti prostřednictvím věstníků vycházejících jako součást periodika Moravský legionářr. Tyto věstníky můžeme označit za poměrně útočné a mravokárné. Najdeme v nich kritiku společenských poměrů, politické scény i směřování vývoje státního aparátu. ${ }^{53}$ Striktně se vymezovaly proti kuřákům a alkoholismu.

51 Moravský legionář 4, č. 42, 16. 10. 1924, s. 3.

52 Oficiální vyjádření důvodů vzniku uskupení popsal František Loubal ve svém článku Proč se organisujeme? „Právě proto jest treba si ujasniti, proč jsme si založili spolek. Kořeny jeho založeni tkvi vlastně ještě v době, kdy náš pluk existoval. Byly to chvile, na které nikdy v životě nezapomeneme. Po bývalé rakouské vojančině, kde bylo zavedené kastovnictvi v nejuyšši míre a kde náš český anebo slovenský clověk byl stygmatisován za zrádce a dle toho s ním jednáno, kdy sloužili jsme zájmům nám úplně cizím a dle toho jsme se mnozi též řidili, začali jsme najednou sloužit národu vlastnímu a státu našemu. Již tato okolnost pưsobila na nás, kteři jsme vyšli z tělocvičen sokolských aneb dělnických, mocně. Jsouce zvykli z našich organisaci disciplině a službě národu, postavili jsme svoje schopnosti a též i svoje životy aspoň ve dvanácté hodině do služby té věci, které jsme nemohli před hodinou dvanáctou sloužiti tak, jak sloužili bratři legionárí. Jsme si toho rozdílu vědomi a jsme si vědomi předevšim té práce, kterou bratři legionáři vykonali za nás všechny, kteři jsme se nedostali na druhou stranu. A právě proto s nadšením, které mohl v nás vychovati jen Tyrš, jsme se postavili do služeb národa, kdy potřeboval doma v době všeobecného zmatku popřevratového lidi oddaných a spolehlivých jako soli. “ Moravský legionár 4, č. 41, 9. 10. 1924, s. 5.

53 Moravský legionář 5, č. 28, 9. 7. 1925, s. 4. 


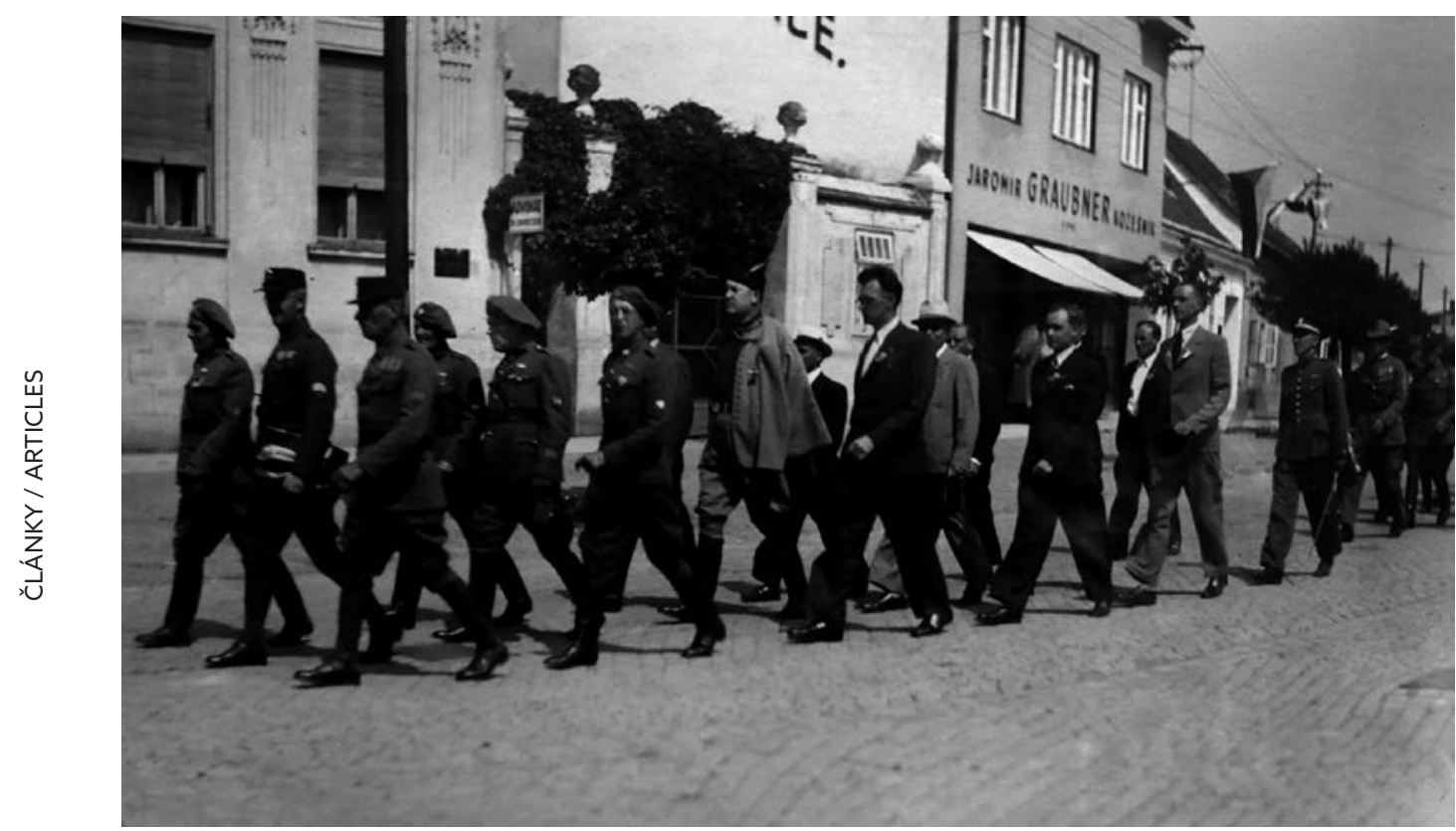

Branný sraz ve Strážnici ukazuje svornou spolupráci ve společném pochodu legionářských a nelegionářských veteránů (Městské muzeum ve Strážnici).

Předáci sdružení se angažovali v přípravách a realizaci Husových oslav v roce 1925. Zmínku o jejich účasti na oslavách narozenin T. G. Masaryka však v tisku nenajdeme. Zůstává otázkou, zda se jedná o náhodu, nebo cílený bojkot. Můžeme však odvodit, že historické motivy hrály pro členy sdružení větší úlohu než osobnosti zahraničního odboje. Patrně se nejednalo o homogenní skupinu mužů. Jako poslední veřejné vystoupení na stranách denního tisku můžeme označit článek odsuzující nárůst fašistických tendencí v české společnosti, po jehož uveřejnění vydávání věstníku skončilo. ${ }^{54}$ Můžeme prozatím pouze spekulovat, zda došlo k vnitřnímu názorovému rozkolu, nebo vydávání věstníku ustalo z objektivních důvodů nedostatku časových nebo finančních prostředků.

V pozdějších letech se dobrovolníci organizovali předně v Československé obci dobrovolců a sdruženích příslušníků domácího vojska. Jejich činnost byla, podobně jako činnost legionářů, narušená třenicemi, které vznikaly mezi jednotlivými organizacemi. Spolupráce se v některých regionech dařila lépe, jinde hůře. V Unhošti si napřríklad veteráni domácího vojska stěžovali, že jsou poškozováni příslušníky čs. domobrany z Itálie, kteří se vždy v průvodech řadí před ně, přestože nepožívají zvláštních výsad. Vyjádření Ministerstva národní obrany vyznělo ve smyslu, že by se zástupci obou organizací měli na druhém místě střídat (po legionářích, kteří stále požívali výsadního postavení). ${ }^{55}$ Při

54 Morauský legionár 6, č. 24, 10. 6. 1926, s. 3.

55 Legionářská stráž 17, č. 28, 25. 6. 1937, s. 5. 
sjezdu legionářů v Uherském Hradišti 4. července 1938 došlo k podobnému přehmatu, který byl však záhy urovnán legionáři.

Na jihu Moravy projevovali aktivitu členové Sdružení př́slušníků bývalé Slovácké brigády. Tito 10. dubna 1938 obnovili slavnostní př́sahu republice v Hodoníně. Následně se pravidelně zúčastňovali vojenských slavností. Dokonce spolupořádali branné srazy (22. května 1938 v Hodoníně a 19. června 1938 ve Strážnici). Na podzim 1938 se chystaly kolosální oslavy 20. výročí samostatnosti, místo nich však přišlo jen zklamání a tryzny. Možná právě velký tlak na bojeschopnost a morálku čs. armády zapř́ičinil mnoho osobních tragédií, kdy se někteř́ branci nedokázali vyrovnat $\mathrm{s}$ faktem, že nemohli bránit milovanou vlast.

Branný sraz ve Strážnici ukazuje svornou spolupráci ve společném pochodu legionářských a nelegionářských veteránů (Městské muzeum ve Strážnici).

\section{Závěr}

Konec první světové války a osamostatnění českých zemí od Rakouska stvořilo příhodné prostředí pro oslavy. Slavit se s účastí armády začalo ihned 28. řínna 1918. Vzpomínková kultura se formovala v prvních letech Československa, ale musela dočasně ustoupit palčivějším problémům. Objevila se i kritika př́lišného množství festivit. Teprve s návratem čs. legionářů z Ruska a unifikací čs. branné moci se ustálily nejvýznamnější svátky oslavované armádou - 28. říjen, 7. březen a 2. červenec (vznik ČSR, narozeniny TGM, bitva u Zborova). Vedle nich armáda slavila další významná výročí založení plukủ a bitev. Jednalo se vesměs o legionářské tradice. Nelegionářské vojenské jednotky a domácí odboj byly upozaděny. Ve výběru slavených událostí lze spatřit i zahraniční vliv (zejména francouzské vojenské mise př̀ čs. armádě). Teprve s nástupem nacismu k moci v Německu a nutností se zabývat otázkami obranyschopnosti československé společnosti bylo využito i nelegionářských veteránských spolků k vytváření dojmu sjednocení k obraně vlasti. Díky tomu byly tyto spolky a bojové úspěchy jejich členů více prezentovány veřejnosti. Do proměn svátkového kalendáře již však prakticky nezasáhly.

Př́klady z historie komemorací prvorepublikové armády nám ukazují, že pospolitost funguje, pokud máme vnějšího nepřítele. $V$ dobách míru, kdy nehrozilo přímé nebezpečí války vzplály drobné půtky, které vrcholily znepřátelením spolků, které byly klíčové pro spolupráci s armádou na vojenských oslavách. Vojtěch Kessler však poukázal na fakt, že ani v době ohrožení vlasti nacistickým Německem nebyla čs. společnost bezezbytku sjednocená. ${ }^{56}$ Vedle Československé obce legionářské působily také jiné veteránské legionářrské organizace a vedle nich také řada nelegionářských. Revoluční heslo Volnost - rovnost - bratrstvi tedy nedošlo naplnění beze zbytku ani v době ohrožení „výsledků revoluce“.

Prvorepubliková společnost vystavěná na historických tradicích i nové vrstvě legionářských tradic se profilovala spíše liberálně a ateisticky. Přesto můžeme spekulovat o spatřování sakrálních prvků v ceremoniálech sekularizovaných svátků. ${ }^{57}$ Tyto prvky

56 Sláva republice!, s. 205.

57 Tamtéž, s. 23. 
lze vysledovat právě ve vojenském prostředí. Když odhlédneme od přímého propojení festivity s bohoslužbou, můžeme sledovat průběh pietního aktu, který měl a dodnes má určitou podobu. Vojenské povely a cviky musí být prováděny v přesném pořadí, $\mathrm{s}$ určitou noblesou, ale i rázností. Mnohdy jsou pietní akty doprovázeny ohněm (v podobě „věčného ohně“ nebo pochodní) nebo světlem lampionů. Akt kladení věnců doprovází hudba, stejně jako příchod a odchod vojenských praporů (v tomto případě husitský chorál Kdož sú boži bojouníci). Vše vrcholí českou (mnohde dodnes i československou) státní hymnou. $\mathrm{V}$ přeneseném významu nám toto vše může připomínat křestanskou liturgii. Nacházíme tedy i v prvorepublikové státnosti prvky politického náboženství?

Nedílnou součástí prvorepublikové vzpomínkové kultury se stali oba prezidenti. Hráli jak roli pasivní, kdy byly oslavovány jejich narozeniny, tak aktivní, kdy se přímo účastnili oslav. Jejich politické směřování se velmi podobalo a Edvard Beneš v mnohém na Tomáše G. Masaryka navazoval. Přesto můžeme spatřovat zásadní rozdíly v jejich sebeprezentaci. I ta se však vyvíjela v čase a možná byla přímou reakcí na dějinné procesy dané doby. T. G. Masaryk v prvních letech existence republiky, kdy docházelo k řadě sporů o hranice nového státu, přijal roli silného národního vůdce. Přesto se neuchyloval k militantním diktátorským gestům. Jeho vzezření bylo civilního rázu a odpovídalo spíše označení „filozof na trůně“. To se začalo měnit v průběhu 20. let, kdy se Masaryk prezentoval jako ztepilý muž a rázný prezident nosící přiléhavý oblek téměř vojenského střihu s čepicí familiárně přezdívanou „Masaryčka“, která se střihem velmi podobala pokrývkám hlavy čs. legionářu v Rusku. Masaryk byl často portrétován na koni a v majestátních pózách. Naproti tomu Edvard Beneš se od počátku výkonu prezidentské funkce do roku 1938 prezentoval jako civilista a diplomat (vojenský stejnokroj oblékal až po roce 1945). ${ }^{58}$ Snad se tím snažil kontrovat militantním fašistickým vůdcům, kteří získávali v Evropě čím dál silnější pozice.

Chování prezidentů a jejich sebeprezentace ukazují spíše na snahu vytváření protiváhy společenským náladám. První léta svobody přinesla řadu problémů. Boj proti vnějšímu nepříteli znamenal nutnost se sjednotit. Festivity, kterých se armáda účastnila, měly výchovný ráz. K cílům vojenských představených patřila bezproblémová unifikace a nivelizace jednotlivých armádních složek. S potlačením nejpalčivějších problémů zahraniční politiky a rozvojem mírového hnutí jdou snahy o bojeschopnost armády stranou. Počíná ekonomické soupeření států a projevují se vnitřní spory československých národnostních skupin. Postupně se také rozevírají nůžky mezi legionáři a nelegionáři. Drobné tř̌enice však vznikaly i mezi skupinami nelegionářů - mezi veterány čs. domobrany z Itálie a domácího vojska. S těmito muži se spory přenesly i do veteránských organizací meziválečného Československa. Tento fenomén byl tlumen teprve s opětovnou eskalací hrozby války. Armádní a politické špičky kooptovaly nelegionářské veteránské organizace do vzpomínkové kultury teprve ve druhé polovině 30. let. Můžeme se ptát, jestli to nebylo už poněkud pozdě. Nabízí se však také otázka, jestli již mnohem dříve neměly pracovat na začlenění jiných národností do obrany československého státu - aby i jiné národnosti přijaly čs. stát za svůj. 


\section{Liberté - égalité - fraternité? Military commemorations of the First Czechoslovak Republic in non-legionary veterans perspective.}

The paper contains an analysis of military aspects of The First Czechoslovak Republic festivities and commemorations. The observed time period is divided into three stages - the first: the era of creating of new traditions and their propagation at the dawn of the First Czechoslovak Republic (1918-1920); the second: the time of stabilization of the festive schedule and shape of commemorations during years 1920-1935; the third: final intensification of festivities organized in the escalated international situation (1936-1938). After the first years of the First Czechoslovak Republic filled with lots of commemorations, three main military holidays were established: the birthday of the President, T. G. Masaryk (March 7th); the anniversary of battle of Zborov (July 2nd) and the anniversary of the declaration of Republic (October 28th). The shaping of military traditions was mostly under control of the ex-Legionary part of Army officers. Non-legionary military veteran organisations and officers quickly fell out of favour and their merits were often concealed from public. In the years of The First Czechoslovak Republic, the administration of the army and of the state started putting effort into unifying the society in order to defend the Republic's sovereignty and existent. Merits of Home Guards, Czechoslovak Militia from Italy and civil resistance during WWI were presented by integration into military ceremonies. However this short and unsystematic process couldn't equalize the gap between the former members and non-members of the Czechoslovak Legion. 
